$\begin{array}{rr}\text { FIT(PATOLOGI } & \text { Volume 11, Nomor 5, Oktober 2015 } \\ \text { I N D ONESIA } & \text { Halaman 166-174 } \\ \text { ISSN: } 0215-7950 & \text { DOI: } 10.14692 / \text { jfi.11.5.166 }\end{array}$

\title{
Risiko Introduksi Gandum ke Timor Tengah Utara: Penyakit Hawar Daun dan Busuk Batang
}

\author{
Risk of Wheat Introduction to Timor Tengah Utara: \\ Leaf Blight and Stem Rot Disease
}

\author{
Aloysius Rusae, Efi Toding Tondok, Suryo Wiyono* \\ Institut Pertanian Bogor, Bogor 16680
}

\begin{abstract}
ABSTRAK
Tanaman gandum berpotensi untuk dikembangkan di Timor Tengah Utara (TTU). Penyakit merupakan salah satu risiko dalam introduksi gandum. Keberadaan penyakit gandum belum diketahui karena belum pernah dilakukan penanaman gandum di daerah tersebut. Penelitian ini bertujuan membuktikan serangan penyakit utama yang menyerang tanaman gandum apabila diintroduksi ke TTU. Metode yang digunakan ialah penanaman gandum di TTU, pengamatan penyakit, dan identifikasi penyakit utama. Gandum yang ditanam di lapangan ialah varietas Dewata, Selayar, dan Nias. Pembuktian patogen dilakukan dengan mengikuti postulat Koch. Identifikasi patogen dilakukan dengan karakterisasi morfologi. Penyakit penting pada gandum yang ditemukan di TTU ialah penyakit hawar daun dan busuk batang. Hasil postulat Koch menunjukkan bahwa Helminthosporium gramineum penyebab penyakit hawar daun dan Rhizoctonia sp. penyebab busuk batang. Insidensi penyakit di lapangan mencapai $82-93 \%$ dan $11-22 \%$, berturut-turut untuk penyakit hawar daun dan busuk batang. Keparahan penyakit hawar daun dan penyakit busuk batang pada vari. Dewata paling rendah bila dibandingkan pada gandum var. Selayar dan Nias.
\end{abstract}

Kata kunci: Helminthosporium gramineum, postulat Koch, Rhizoctonia sp.

\begin{abstract}
Wheat has a great potency to be cultivated in Timor Tengah Utara (TTU). However, disease is one of the risks for introduction of wheat. The existence of wheat disease in TTU is unknown because wheat has never been grown in this area. This study aims to determine the potential risks of major diseases that will infect wheat plants when introduced to the TTU. The methods used in this study consisted of wheat cultivation in the field, followed by observation and identification of the main diseases on wheat. Wheat varieties grown in field were Dewata, Selayar and Nias. Koch's postulate were performed to identify the suspected microbes as pathogens. Morphological-based identification was applied on the isolated pathogens. The main diseases on wheat cultivated in TTU were leaf blight and stem rot. The results of Koch's postulate showed that Helminthosporium gramineum and Rhizoctonia sp. was the causal of leaf blight and stem rot, respectively. Disease incidence reached $82-93 \%$ and $11-22 \%$ for leaf bligh and stem rot disease, respectively. Disease severity of leaf blight and stem rot on var. Dewata was the lowest compared to var. Selayar and var. Nias.
\end{abstract}

Key words: Helminthosporium gramineum, Koch's postulate, Rhizoctonia sp.

\footnotetext{
*Alamat penulis korespondensi: Departemen Proteksi Tanaman, Fakultas Pertanian, Institut Pertanian Bogor Jalan Kamper, Kampus IPB Darmaga, Bogor 16680.

Tel: 0251-8629364,Faks : 0251-862362, Surel : suryow@hotmail.com
} 


\section{PENDAHULUAN}

Kebutuhan gandum Indonesia setiap tahun mengalami peningkatan, hal ini terjadi karena perubahan pola makan masyarakat yang telah bergeser ke makanan yang berbasis tepung terigu seperti mie instan dan roti. Indonesia mengimpor gandum dari berbagai negara untuk mencukupi kebutuhan gandum dalam negeri. Pada tahun 2010 impor gandum Indonesia mencapai 4.5 juta ton dan mengalami peningkatan 4.8 juta ton pada tahun 2011 (BPS 2012).

Hasil penelitian membuktikan bahwa gandum dapat tumbuh dan berproduksi dengan baik di Indonesia serta mempunyai peluang untuk pengembangannya, namun perlu diperhatikan pengaruh suhu dan curah hujan yang menyebabkan naiknya intensitas penyakit terutama menjelang panen (Wyczling et al. 2010). Hujan yang terlalu banyak pada waktu pembungaan, mengakibatkan banyak hampa dan mudah terserang penyakit. Di Kabupaten Timor Tengah Utara (TTU) beberapa kecamatan memiliki ketinggian 500 sampai $1000 \mathrm{~m}$ dpl, suhu udara $22-34{ }^{\circ} \mathrm{C}$, kelembapan udara $69-87^{\circ} \mathrm{C}$ dan penyinaran matahari $50-98 \%$ (BPS 2013). Berdasarkan kondisi ini beberapa kecamatan berpotensi untuk budi daya gandum. Salah satu risiko introduksi tanaman di suatu daerah ialah serangan penyakit baru, karena tidak terdapat musuh alami OPT tersebut di daerah itu.

Pengetahuan tentang keberadaan patogen sangat penting untuk menentukan peta sebaran patogen, juga untuk menentukan langkah pengelolaan patogen tersebut lebih lanjut sehingga diharapkan dapat meningkatkan produksi gandum. Oleh karena itu penelitian ini dilakukan untuk membuktikan keparahan penyakit gandum bila diintroduksi di Kabupaten TTU, Provinsi Nusa Tenggara Timur.

\section{BAHAN DAN METODE}

\section{Penanaman Gandum}

Penanaman gandum dilaksanakan di Kelurahan Oenak, Kecamatan Noemuti,
Kabupaten TTU. Benih yang digunakan ialah gandum var. Dewata, Nias, dan Selayar yang merupakan varietas terseleksi dan beradapatasi di daerah tropik. Tanaman gandum ditanam secara langsung, benih ditempatkan pada lubang tanam secara tunggal ( 2 butir benih per lubang tanam) dengan jarak tanam $25 \mathrm{~cm} \times 10 \mathrm{~cm}$. Pemupukan dilakukan dengan cara dialur antara barisan tanaman $(5-7 \mathrm{~cm})$. Pupuk pertama diberikan saat 10 hari setelah tanam (HST) dengan dosis $50 \mathrm{~kg} \mathrm{ha}^{-1}$ urea, $100 \mathrm{~kg} \mathrm{ha}^{-1}$ SP36. Pemupukan kedua diberikan saat 30 HST dengan dosis $50 \mathrm{~kg} \mathrm{ha}^{-1}$ urea. Pengendalian gulma dilakukan setiap minggu.

Penelitian disusun dalam rancangan acak kelompok dengan varietas gandum sebagai perlakuan yang terdiri atas var. Dewata, Nias, dan Selayar. Penelitian diulang 4 kali sebagai blok. Setiap blok terdiri atas 3 petak sehingga jumlah keseluruhan petak dalam penelitian ini ialah 12 petak. Jarak antarpetak ialah $0.5 \mathrm{~m}$ dan jarak antarblok ialah $2 \mathrm{~m}$.

\section{Pengamatan Kejadian dan Keparahan Penyakit}

Kejadian penyakitdiamatipada setiappetak perlakuan yang dibuat berukuran $1 \mathrm{~m} \times 0.5 \mathrm{~m}$ sebanyak 3 petak kecil. Seluruh tanaman yang terdapat pada petak tersebut menjadi tanaman sampel. Kejadian penyakit dihitung dari jumlah tanaman sampel yang terserang patogen.

$$
\mathrm{K}=\frac{\mathrm{n}}{\mathrm{N}} \times 100 \% \text {, dengan }
$$

Kp, kejadian penyakit; $\mathrm{n}$, jumlah tanaman yang terserang patogen; $\mathrm{N}$, jumlah tanaman yang diamati dalam setiap perlakuan.

Pengamatan keparahan penyakit dilakukan pada 3 petak kecil berukuran $1 \mathrm{~m} \times 0.5 \mathrm{~m}$ yang dibuat pada setiap petak perlakuan. Pada petak-petak tersebut dilakukan pengacakan untuk menentukan 5 rumpun gandum sebagai tanaman sampel. Keparahan penyakit dihitung dari jumlah tanaman sampel yang terserang penyakit dan diberikan skor sesuai dengan skoring penyakit yang sudah ditentukan (Tabel 1).

$$
\mathrm{IP}=\frac{\Sigma \text { ni.vi }}{\mathrm{N} . \mathrm{V}} \times 100 \% \text {, dengan }
$$


Tabel 1 Skor penyakit hawar daun Helminthosporium pada gandum

\begin{tabular}{lc}
\hline Skor & Kategori serangan $(\%)$ \\
\hline 0 & 0 \\
1 & $0 \leq \mathrm{X} \leq 5$ \\
2 & $5 \leq \mathrm{X} \leq 20$ \\
3 & $20 \leq \mathrm{X} \leq 40$ \\
4 & $>40$ \\
\hline
\end{tabular}

IP, keparahan penyakit; ni, jumlah tanaman dengan skor ke-i; vi, nilai skor penyakit ke-i; $\mathrm{N}$, jumlah tanaman yang diamati; $\mathrm{V}$, skor tertinggi (Horsfall dan Barratt 1945).

Data kejadian dan keparahan penyakit yang diperoleh dianalisis menggunakan analisis sidik ragam, dan perlakuan yang berpengaruh nyata dianalisis lanjut dengan uji Duncan (DMRT).

\section{Postulat Koch}

Cendawan patogen penyebab penyakit pada tanaman gandum diamati dari strukturnya yang terdapat pada permukaan tanaman sakit. Gejala dan tanda penyakitnya dideskripsikan.

Bagian tanaman gandum (daun atau batang) yang bergejala dibersihkan dengan air kemudian dipotong-potong dengan ukuran $\pm 3 \mathrm{~cm}$. Potongan tersebut dicelupkan dalam larutan natrium hipoklorit $1 \%$ dan alkohol 70\% masing-masing selama 1 menit, kemudian dibilas dengan air steril sebanyak 3 kali dan dikeringkan di atas kertas saring. Potongan daun ditanam pada medium agaragar dekstrosa kentang (ADK) dengan kloramfenikol $0.01 \%$ untuk mencegah pertumbuhan bakteri. Cendawan yang tumbuh dimurnikan sebagai koleksi biakan.

Cendawan diidentifikasi berdasarkan morfologinya menggunakan mikroskop dan untuk membuktikan apakah cendawan merupakan patogen maka isolat tersebut diinokulasikan pada bagian (daun atau batang) tanaman gandum sehat yang berumur 3 minggu. Daun disemprot dengan air steril, dibersihkan menggunakan natrium hipoklorit $3 \%$, dan dibilas dengan air steril. Potongan biakan murni patogen berumur 10 hari ditempelkan pada bagian daun, kemudian ditutup dengan kapas yang dibasahi air steril dan diselotip. Tanaman tersebut disungkup untuk menghindari infeksi dari patogen lain.

Pengamatan perkembangan penyakit pada tanaman gandum dilakukan setiap hari sampai menampakkan gejala. Gejala yang muncul dicatat, dideskripsikan dan dibandingkan dengan gejala awal di lapangan.

Apabila hasil inokulasi memperlihatkan gejala yang sama maka bagian ini diisolasi kembali. Suatu cendawan dinyatakan sebagai patogen apabila hasil isolasi dapat dibuktikan sama dengan yang diinokulasikan.

\section{Karakterisasi Cendawan Patogen}

Cendawan patogen diamati secara makroskopis dari ciri khas seperti warna, bentuk, dan tepi koloni dan mikroskopis dari morfologinya berupa hifa (warna, bersekat atau tidak, pola, dan ukuran percabangan), konidium (bentuk, warna, dan ukuran), dan konidiofor (warna, bersekat atau tidak, bercabang atau tidak, dan ukuran). Cendawan patogen yang diperoleh diidentifikasi dengan kunci identifikasi Parmeter (1970), Putterill (1954), Roberts (1999), Manamgoda et al. (2014) dan Toda et al. (2007). Pengamatan pertumbuhan cendawan bertujuan menentukan kecepatan pertumbuhan dengan mengukur diameter koloni sampai hari ke-7 atau saat koloni telah mencapai tepi cawan petri.

\section{HASIL}

\section{Penyakit Gandum di Timor Tengah Utara}

Beberapa penyakit yang menginfeksi tanaman gandum di TTU ialah hawar daun, bercak daun, busuk batang, busuk pucuk, penyakit daun terpilin, dan hawar malai (Tabel 2). Penyakit hawar daun dan penyakit busuk batang merupakan penyakit terpenting pada tanaman gandum. Kedua penyakit tersebut belum pernah ditemukan di Indonesia.

\section{Kejadian dan Keparahan Penyakit Hawar Daun dan Busuk Batang}

Terdapat perbedaan kejadian dan keparahan penyakit hawar daun pada 3 varietas yang diuji. Secara umum gandum var. Dewata memiliki kejadian penyakit hawar daun paling 
rendah dan berbeda nyata dengan var. Selayar. Keparahan penyakit hawar daun pada gandum var. Dewata paling rendah dan berbeda nyata dengan var. Nias dan Selayar (Tabel 3).

Pengamatan kejadian penyakit busuk batang menunjukkan bahwa, gandum var. Dewata memiliki kejadian penyakit yang rendah dan berbeda nyata dengan gandum var. Selayar. Gandum var. Selayar memiliki kejadian penyakit busuk batang yang tinggi di antara varietas yang lain.

\section{Penyakit Hawar Daun}

Postulat Koch yang dilakukan menunjukkan bahwa patogen tersebut merupakan penyebab hawar daun. Cendawan yang diinokulasikan pada daun tanaman gandum menunjukkan gejala awal berupa bercak kuning pada tepi titik inokulasi terbentuk pada 1 HST dan 3 HST, pada titik inokulasi mengalami nekrosis. Nekrosis tersebut meluas menjadi hawar yang berwarna cokelat dan kering. Gejala tersebut memiliki kesamaan dengan gejala di lapangan. Gejala penyakit hawar daun mulai nampak pada fase vegetatif, yaitu 14 HST. Patogen ini menyerang dari daun pertama, berupa bercak kecil yang dikelilingi warna kekuningan, selanjutnya bercak-bercak membesar membentuk lesio yang memanjang berwarna cokelat, menyatu pada seluruh permukaan daun tanaman, kemudian daun menjadi kering dan rapuh (Gambar 1).

Identifikasi terhadap patogen hawar daun yang diuji menunjukkan bahwa

Tabel 2 Inventarisasi penyakit pada stadium pertumbuhan gandum

\begin{tabular}{|c|c|c|c|c|}
\hline \multirow{2}{*}{ Varietas } & \multicolumn{2}{|c|}{ Fase Vegetatif } & \multicolumn{2}{|c|}{ Fase Generatif } \\
\hline & Penyakit & Penyebab penyakit & Penyakit & Penyebab penyakit \\
\hline \multirow[t]{5}{*}{ Nias } & Hawar daun & Helminthosporium & Hawar malai & Helminthosporium \\
\hline & Bercak daun & Curvularia & & Curvularia \\
\hline & Busuk batang & Rhizoctonia & & \\
\hline & Busuk pucuk & Fusarium & & \\
\hline & Penyakit daun terpilin & & & \\
\hline \multirow[t]{5}{*}{ Selayar } & Hawar daun & Helminthosporium & Hawar malai & Helminthosporium \\
\hline & Bercak daun & Curvularia & & Curvularia \\
\hline & Busuk batang & Rhizoctonia & & \\
\hline & Busuk pucuk & Fusarium & & \\
\hline & Penyakit daun terpilin & & & \\
\hline \multirow[t]{5}{*}{ Dewata } & Hawar daun & Helminthosporium & Hawar malai & Helminthosporium \\
\hline & Bercak daun & Curvularia & & Curvularia \\
\hline & Busuk batang & Rhizoctonia & & \\
\hline & Busuk pucuk & Fusarium & & \\
\hline & Penyakit daun terpilin & & & \\
\hline
\end{tabular}

*Fase perkecambahan tidak ada serangan penyakit

Tabel 3 Kejadian dan keparahan penyakit utama gandum di TTU

\begin{tabular}{|c|c|c|c|c|c|c|c|}
\hline \multirow{2}{*}{ Penyakit } & \multirow{2}{*}{ Varietas } & \multicolumn{3}{|c|}{ Kejadian Penyakit (\%) } & \multicolumn{3}{|c|}{ Keparahan Penyakit (\%) } \\
\hline & & $4 \mathrm{MST}$ & $8 \mathrm{MST}$ & $12 \mathrm{MST}$ & $4 \mathrm{MST}$ & $8 \mathrm{MST}$ & $12 \mathrm{MST}$ \\
\hline Hawar & Nias & $10.65 \mathrm{a}$ & $43.54 \mathrm{a}$ & $76.76 \mathrm{a}$ & $21.86 \mathrm{a}$ & $62.33 \mathrm{a}$ & $84.81 \mathrm{~b}$ \\
\hline daun & Selayar & $15.46 \mathrm{~b}$ & $47.68 \mathrm{a}$ & $87.93 \mathrm{~b}$ & $22.64 \mathrm{a}$ & $63.96 \mathrm{a}$ & $92.69 \mathrm{c}$ \\
\hline & Dewata & $11.15 \mathrm{a}$ & $42.51 \mathrm{a}$ & $73.45 \mathrm{a}$ & $21.22 \mathrm{a}$ & $61.66 \mathrm{a}$ & $81.89 \mathrm{a}$ \\
\hline Busuk & Nias & $5.87 \mathrm{a}$ & $9.79 \mathrm{a}$ & $16.84 \mathrm{ab}$ & & & \\
\hline batang & Selayar & $7.54 \mathrm{a}$ & $12.54 \mathrm{a}$ & $21.76 \mathrm{~b}$ & - & - & - \\
\hline & Dewata & $3.89 \mathrm{a}$ & $5.93 \mathrm{a}$ & $11.30 \mathrm{a}$ & & & \\
\hline
\end{tabular}

MST, minggu setelah tanam

Angka pada kolom yang diikuti dengan huruf yang sama menunjukkan tidak berbeda nyata menurut uji Duncanpada $\alpha 5 \%$. 
cendawan patogen tersebut ialah genus Helminthosporium. Koloni cendawan berwarna putih kehijauan sampaikehitaman, mulai hari ke-4 terbentuk zona konsentris dan terdapat miselium aerial. Pada hari ke-5-7 koloni memenuhi cawan petri (Gambar 2). Secara umum pertumbuhan Helminthosporium sp. sangat cepat pada medium ADK. Hifa cendawan ini bersekat, hialin dan menjadi kuning kecokelatan sejalan dengan pertambahan umur. Rata-rata kecepatan pertumbuhan koloni $1.29 \mathrm{~cm}$ per hari. Konidiofor Helminthosporium sp. bersekat dan tidak bercabang, dengan panjang 21-322 $\mu \mathrm{m}$, rerata $184.39 \mu \mathrm{m}$ dan lebar 2.50-6.25 $\mu \mathrm{m}$, rerata $4.66 \mu \mathrm{m}$. Pembentukan konidium mulai pada hari ke-5 dan semakin banyak pada hari ke-15. Konidium muda berwarna hialin, konidium matang berwarna kuning kecokelatan sampai kehitaman, memiliki 1-7 sekat. Konidium berbentuk oval panjang, bagian tengahnya membesar dan kedua ujungnya mengecil

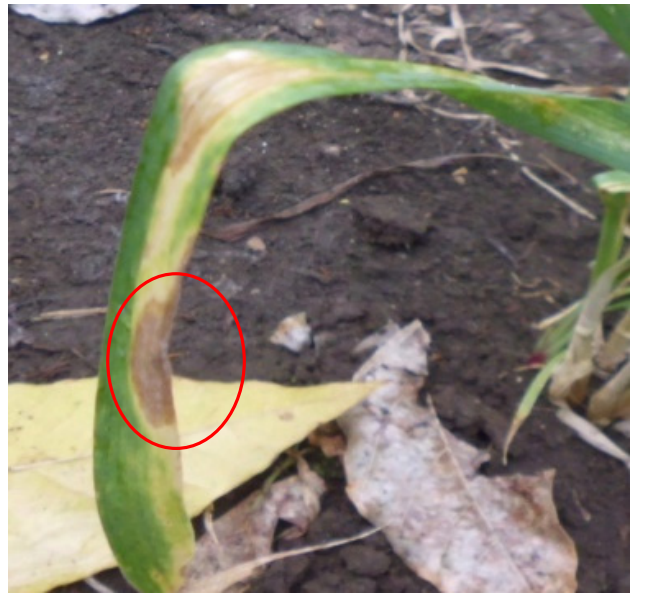

a dan tumpul (Gambar 2). Ukuran konidium bervariasi dengan panjang 10.5-50.59 $\mu \mathrm{m}$ dan lebar 7-23.53 $\mu \mathrm{m}$, rerata panjang konidium $26.95 \mu \mathrm{m}$ dan lebar $11.01 \mu \mathrm{m}$. Perbandingan karakter morfologi Helminthosporium hasil isolasi dengan yang telah diketahui spesiesnya (Putterill 1954). Berdasarkan karakter morfologi dan pertumbuhan koloni, isolat dari gandum lebih mirip dengan Helminthosporium gramineum (Tabel 4).

\section{Penyakit Busuk Batang}

Pengujian dengan postulat Koch membuktikan bahwa cendawan yang diuji tersebut ialah patogen busuk batang pada gandum. Gejala yang nampak pada tanaman gandum yang diinokulasi patogen tersebut ialah tumbuh bercak pada pelepah daun dan daun pada 16 hari setelah inokulasi. Daun yang terinfeksi awalnya berupa titik kuning, berkembang menjadi bercak cokelat, kemudian nekrotik pada seluruh daun dan menjadi

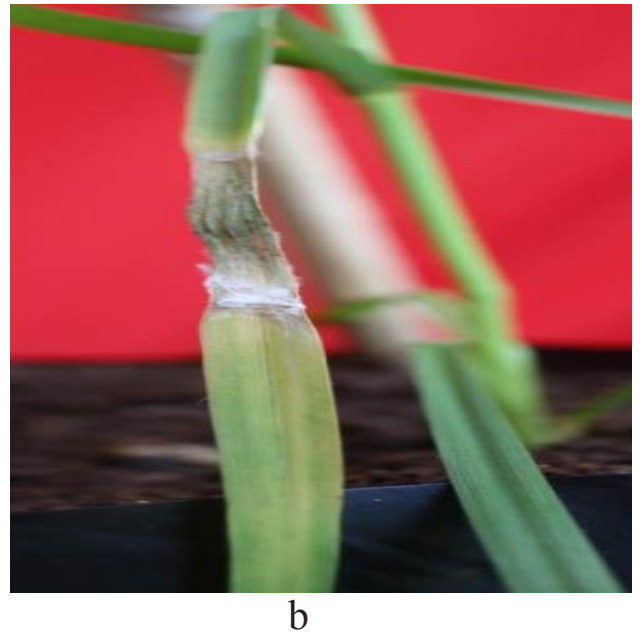

$\mathrm{b}$

Gambar 1 Gejala penyakit hawar daun. a, gejala di lapangan dan b, gejala hasil inokulasi.

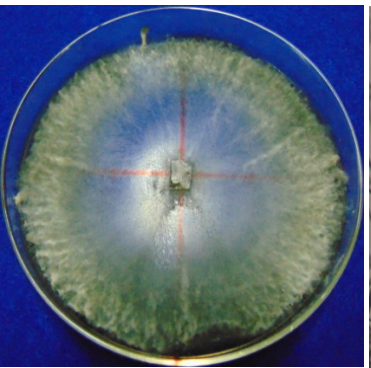

a

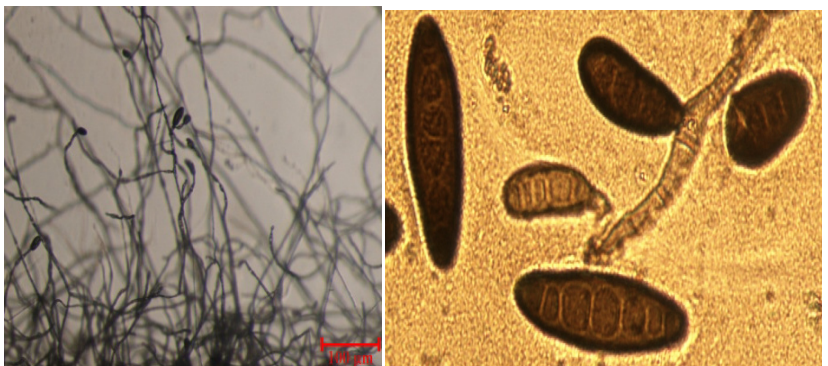

b c

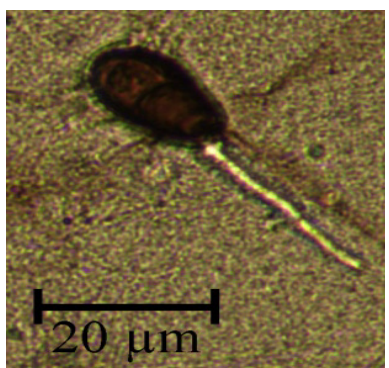

d

Gambar 2 Bentuk koloni dan morfologi Helminthosporium gramineum. a, koloni pada medium agar-agar dekstrosa kentang; b, konidiofor; c, konidium; dan d, perkecambahan konidium. 
kering, infeksi pada pelepah daun berupa lapangan. Penyakit busuk batang tampak jelas bercak cokelat yang semakin besar seiring pada fase vegetatif. Gejala awal berupa bercak pertambahan waktu. Pada pangkal batang kecil berwarna kuning pada daun pertama terdapat bercak cokelat yang berkembang pada diujung atau tepi daun, kemudian daun menjadi seluruh pangkal batang dan menjadi busuk nekrosis dan kering yang berawal dari tepi atau berwarna cokelat kehitaman (Gambar 3). ujung daun, bahkan mati. Gejala yang tampak Hal ini sesuai dengan gejala yang terdapat di pada pangkal batang ialah adanya bercak-

Tabel 4 Karakter Helminthosporium asal gandum di TTU dan Helminthosporium yang telah diketahui spesiesnya

\begin{tabular}{|c|c|c|c|c|}
\hline Karakter & $\begin{array}{l}\text { Helminthosporium } \\
\text { hasil isolasi }\end{array}$ & $\begin{array}{l}\text { H. sorokiniana } \\
\text { (Manamgoda et al. } \\
\text { 2014) }\end{array}$ & $\begin{array}{l}\text { H. gramineum } \\
\text { Rabenh } \\
\text { (Putterill 1954) }\end{array}$ & $\begin{array}{l}\text { H. sativum } \\
\text { (Putterill 1954) }\end{array}$ \\
\hline \multicolumn{5}{|l|}{ Koloni } \\
\hline Warna & putih kehijauan & beludru abu-abu & - & abu-abu \\
\hline Tekstur permukaan & berserabut & - & & \\
\hline Bentuk tepi & rata-tidak beraturan & teratur & - & - \\
\hline \multicolumn{5}{|l|}{ Konidiofor } \\
\hline Ada tidaknya sekat & bersekat & bersekat & bersekat & bersekat \\
\hline Percabangan & tidak & kadang bercabang & tidak & kadang bercabang \\
\hline \multicolumn{5}{|l|}{ Ukuran } \\
\hline Panjang $(\mu \mathrm{m})$ & $21-322$ & $52-310$ & $30-200$ & $60-300$ \\
\hline Lebar $(\mu \mathrm{m})$ & $2.50-6.25$ & $6-8$ & $5-9$ & $6-8$ \\
\hline \multicolumn{5}{|l|}{ Konidium } \\
\hline \multicolumn{5}{|l|}{ Ukuran $(\mu \mathrm{m})$} \\
\hline Panjang $(\mu \mathrm{m})$ & $10.5-50.59$ & $31-100$ & $20-120$ & $26-120$ \\
\hline Lebar $(\mu \mathrm{m})$ & $7-23.53$ & $15-25$ & $11-22$ & $12-26$ \\
\hline Tersusun & tunggal & tunggal & tunggal & tunggal \\
\hline Warna & kuning kecokelatan & kuning kecokelatan & $\begin{array}{l}\text { kuning } \\
\text { kecokelatan }\end{array}$ & $\begin{array}{l}\text { kuning } \\
\text { kecokelatan }\end{array}$ \\
\hline Bentuk & $\begin{array}{l}\text { lonjong dan sedikit } \\
\text { bengkok }\end{array}$ & $\begin{array}{l}\text { lurus dan } \\
\text { melengkung }\end{array}$ & $\begin{array}{l}\text { lurus dan } \\
\text { silinder }\end{array}$ & $\begin{array}{l}\text { lonjong elips dan } \\
\text { sedikit melengkung }\end{array}$ \\
\hline Jumlah sekat & $1-7$ & $3-12$ & $1-7(8)$ & $3-10$ \\
\hline Perkecambahan & polar & bipolar & polar & bipolar \\
\hline
\end{tabular}

-, tidak dideskripsikan

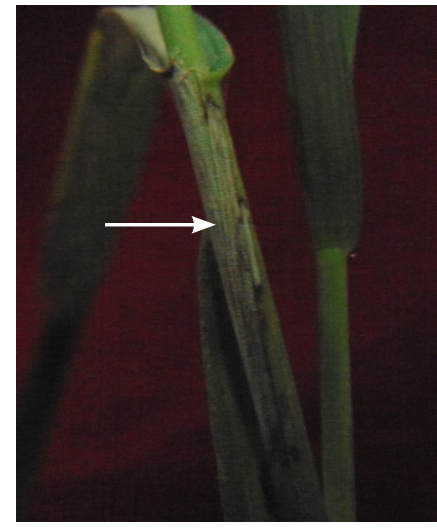

$\mathrm{a}$

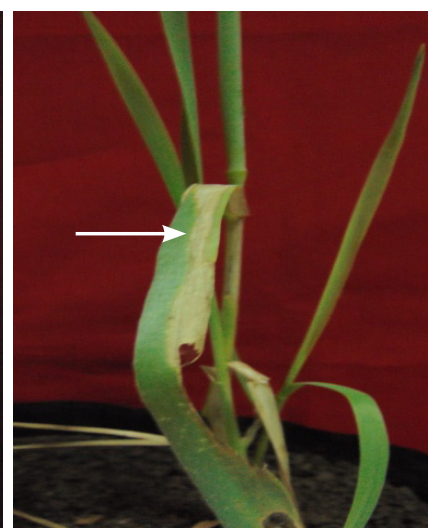

b

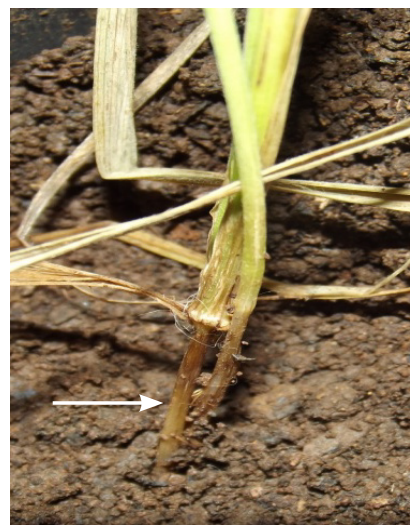

c

Gambar 3 Gejala penyakit busuk batang dengan inokulasi buatan. a, hawar pada pelepah; b, hawar daun; c, busuk pangkal batang. 
bercak cokelat, akar membusuk, berwarna cokelat kehitaman dan jumlahnya berkurang. Pertumbuhan tanaman semakin kerdil, tidak subur dan pada umumnya tidak menghasilkan malai (Gambar 4). Tanaman menghasilkan malai yang pendek, bulir berwarna putih dan hampa pada fase generatif.

Rhizoctonia sp. penyebab penyakit busuk batang memiliki koloni berwarna putih, dengan tepian rata. Miselium cendawan bercabang membentuk jala halus dan bersekat, tidak terbentuk hifa aerial. Hifa mempunyai percabangan yang tegak lurus. Rata-rata kecepatan tumbuh koloni Rhizoctonia sp. ialah $2.25 \mathrm{~cm}$ per hari. Pada hari ke-26 terbentuk sklerotium berwarna putih kemudian berubah menjadi cokelat dengan bentuk tidak beraturan. Diameter hifa Rhizoctonia $2.79 \mu \mathrm{m}$ dengan kisaran 1.5-5 $\mu \mathrm{m}$, awalnya berwarna hialin berkembang menjadi cokelat seiring dengan bertambahnya waktu (Gambar 5). Rhizoctonia sp. hasil isolasi memiliki diameter hifa dan sklerotium yang kecil dibandingkan dengan $R$. solani, R.oryzae dan lebih mendekati $R$. zeae tetapi berbeda ukuran hifa dan sklerotium (Tabel 5).

\section{PEMBAHASAN}

Introduksi tanaman gandum mempunyai risiko serangan penyakit. Penyakit-penyakit yang menyerang tanaman gandum di lapangan menunjukkan risiko penyakit tersebut. Penanaman di lapangan menunjukkan bahwa penyakit hawar daun dan busuk pangkal batang merupakan penyakit terpenting.

Penyakit hawar daun yang disebabkan cendawan $H$. gramineum adalah salah satu penyakit penting pada tanaman gandum di TTU. Kejadian penyakit sangat tinggi

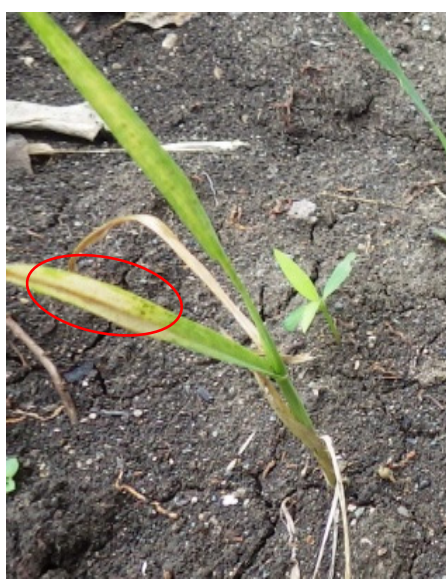

a

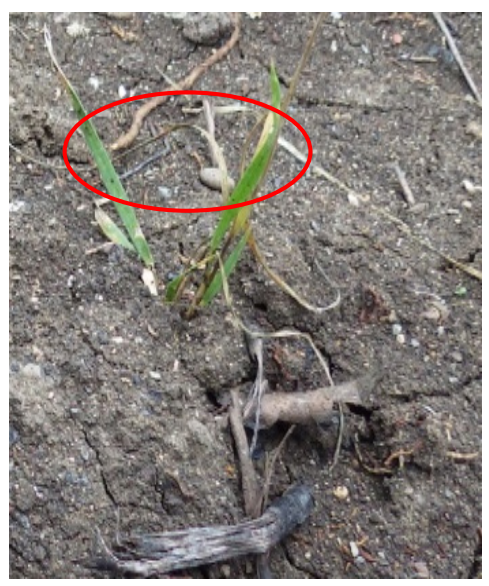

b

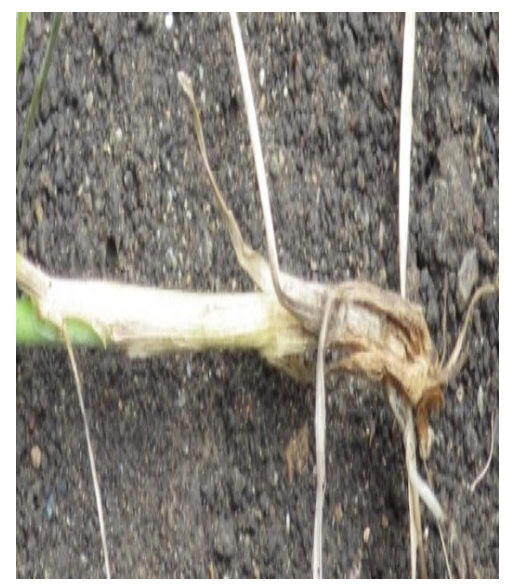

c

Gambar 4 Perkembangan gejala penyakit busuk batang. a, hawar daun; b, tanaman yang mengalami busuk batang; dan c, busuk batang.

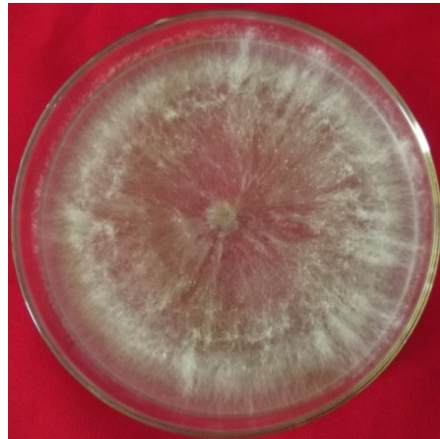

a

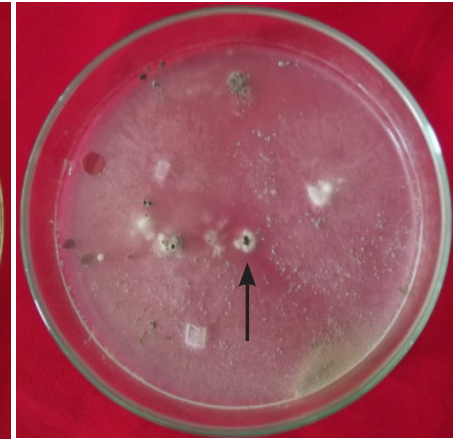

b

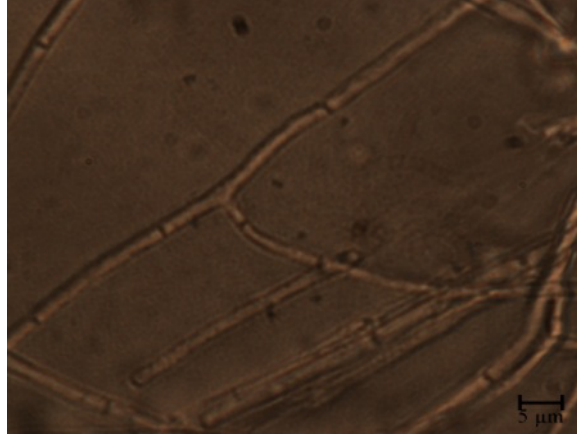

$\mathrm{C}$

Gambar 5 Bentuk koloni dan morfologi Rhizoctonia sp. a, koloni pada medium agar-agar dekstrosa kentang; b, sklerotium; dan c, hifa Rhizoctonia sp. 
Tabel 5 Karakter Rhizoctonia asal gandum di TTU dan Rhizoctonia yang telah diketahui spesiesnya

\begin{tabular}{|c|c|c|c|c|}
\hline Karakter & $\begin{array}{l}\text { Rhizoctonia } \\
\text { hasil isolasi }\end{array}$ & $\begin{array}{l}\text { R. solani. } \\
\text { (Parmeter 1970) }\end{array}$ & $\begin{array}{l}\text { R. oryzae } \\
\text { (Toda et al. 2007) }\end{array}$ & $\begin{array}{l}\text { R. zeae } \\
\text { (Roberts 1999) }\end{array}$ \\
\hline \multicolumn{5}{|l|}{ Koloni } \\
\hline Warna & putih & putih kekuningan & putih-cokelat & putih \\
\hline Tekstur permukaan & $\begin{array}{l}\text { sedikit } \\
\text { berserabut }\end{array}$ & - & - & - \\
\hline Bentuk tepi & rata & - & - & - \\
\hline \multicolumn{5}{|l|}{ Hifa } \\
\hline Ada tidaknya sekat & bersekat & bersekat & bersekat & bersekat \\
\hline Diameter $(\mu \mathrm{m})$ & $1.5-5$ & $4-15$ & $4.8-7.5$ & $2.5-11$ \\
\hline \multicolumn{5}{|l|}{ Sklerotium } \\
\hline Ukuran (mm) & $0.21 \times 0.16$ & $1-3$ & $1-3$ & $0.5-3$ \\
\hline Bentuk & bulat-lonjong & tidak beraturan & bulat tidak beraturan & tidak beraturan \\
\hline Warna & $\begin{array}{l}\text { putih-cokelat, } \\
\text { hitam }\end{array}$ & $\begin{array}{l}\text { putih-cokelat, } \\
\text { kehitaman }\end{array}$ & $\begin{array}{l}\text { merah muda } \\
\text { kekuning-kuningan }\end{array}$ & $\begin{array}{l}\text { merah muda } \\
\text { kecokelatan }\end{array}$ \\
\hline
\end{tabular}

-, tidak dideskripsikan

untuk ke-3 varietas yang diuji berkisar 73.45-87.93\%. Hingga saat ini, dilaporkan bahwa di Indonesia penyakit hawar daun gandum disebabkan oleh $H$. sativum. Hasil pengamatan oleh Nonci et al. (2012) penyakit hawar daun yang disebabkan oleh cendawan H. sativum pada tanaman gandum di Malino, dengan persentase serangan $6.67-68.33 \%$. $H$. gramineum merupakan penyebab penyakit hawar daun gandum yang baru pertama kali dilaporkan di Indonesia.

Di dunia $H$. gramineum dilaporkan di semua negara penghasil gandum. Drechsler (1923) menyatakan bahwa penyakit hawar daun yang disebabkan oleh $H$. gramineum terjadi di hampir semua negara yang menanam gandum, dengan tingkat serangan sekitar 75\%. Negara tersebut ialah Swedia, Denmark, Jerman, Belanda, Inggris, Irlandia, Rusia, Amerika Serikat, Kanada, Argentina, Jepang, Cina, dan India. Keberadaan H. gramineum pada tanaman gandum di lokasi penanaman diduga berasal dari benih dan tanaman inang lain. Gejala penyakit hawar daun $H$. gramineum mulai terlihat pada 14 HST menunjukkan bahwa patogen tersebut terbawa benih. Menurut Watimena (komunikasi pribadi), infeksi Helminthosporium sp. pada benih gandum sangat tinggi, yaitu 54.5\%. Selain itu tanaman inang lain seperti jagung dan sorgum, yang banyak ditanam di sekitar lokasi, berperan sebagai sumber inokulum. Richardson et al. (1976) melaporkan patogen ini menyerang tanaman gandum, jagung dan sorgum di Afrika Selatan.

Respons varietas yang ditunjukkan terhadap patogen hawar daun berbeda. Penelitian lapangan menunjukkan bahwa gandum var. Dewata paling tahan dibandingkan dengan dengan var. Selayar dan Nias. Hasil ini sama dengan yang dilaporkan oleh Nonci et al. (2012) bahwa terdapat 4 varietas yang menunjukkan reaksi tahan terhadap penyakit hawar daun Helminthosporium, yaitu gandum var. Dewata, Menemen, Ali Bey, dan Basri Bey.

Penyakit busuk batang pada penelitian ini dibuktikan dengan postulat Koch disebabkan oleh Rhizoctonia sp. yang memiliki sifat morfologi mirip dengan $R$. zeae. Penyakit busuk batang ini merupakan penyakit tanaman gandum dengan kejadian penyakit antara $11.30 \%$ dan $21.76 \%$. Kejadian penyakit busuk akar yang disebabkan oleh $R$. solani di bagian timur Washington mencapai 11.9\% (Cook et al. 2002). Dengan demikian, introduksi tanaman gandum di TTU perlu diwaspadai karena sebelum penelitian ini, penyakit busuk batang pada gandum di Indonesia yang disebabkan oleh Rhizoctonia belum pernah dilaporkan.

Respons varietas yang ditunjukkan terhadap patogen busuk batang berbeda. Gandum var. Dewata menunjukkan ketahanan 
lapangan yang paling tinggi terhadap dua penyakit, yaitu hawar daun dan busuk batang pada penelitian ini.

\section{DAFTAR PUSTAKA}

[BPS] Badan Pusat Statistik. 2012. Buletin Statistik Perdagangan Luar Negeri Impor 2012. Jakarta (ID): Badan Pusat Statistik.

[BPS] Badan Pusat Statistik. 2013. Statistik Kabupaten Timor Tengah Utara. Kefamenanu (ID): Badan Pusat Statistik Kabupaten Timor Tengah Utara.

Cook RJ, William F, Schillinger, Neil CW. 2002. Rhizoctonia root rot and takeall of wheat in diverse direct-seed spring cropping systems. Can J Plant Pathol. 24:349-358. DOI: http://dx.doi. org/10.1080/07060660209507020.

Drechsler C. 1923. Some graminicolous species of Helminthosporium. J Agric. 24(8):650-656.

Horsfall JG, Barratt RW. 1945. An improved grading system for measuring plant disease. Phytopathology. 35:655.

Manamgoda DS, Rossman AY, Castlebury LA, Crous PW, Madrid H, Chukeatirote E. 2014. The genus Bipolaris. Stud Mycol. 79:221-288. DOI: http://dx.doi. org/10.1016/j.simyco.2014.10.002.

Nonci N, Muis A, Azrai. 2012. Skrining 12 varietas/galur gandum terhadap hama penyakit. Di dalam: Muis A, Aqil M, Syafruddin. Peningkatan Peran Penelitian
Serealia Menuju Pertanian Bioindustri. Seminar Nasional Serealia; 2013 Juni 18; Maros (ID): Balai Penelitian Tanaman Serealia. hlm 387-395.

Parmeter JR. 1970. Rhizoctonia solani: Biology and Pathology. California (US): Univ California Pr.

Putterill KM. 1954. Some Graminicolous Species of Helminthosporium and Curvularia Occurring in South Africa. Bothalia. 6(2):347-378. DOI: http:// dx.doi.org/10.4102/abc.v6i2.1694.

Richardson MJ, Whittle AM, Jacks M. 1976. Yield loss relationships in cereals. Plant Pathol. 25:21-30. DOI: http://dx.doi. org/10.1111/j.1365-3059.1976.tb01910.x.

Roberts P. 1999. Rhizoctonia forming fungi: A Taxonomic Guide. Ed ke-1. Netherlands (NL): Royal Botanic Gardens.

Toda T, Hayakawa T, Mghalu JM, Yaguchi S, Hyakumachi M. 2007. A new Rhizoctonia sp. closely related to Waitea circinata causes a new disease of creeping bentgrass. J Gen Plant Pathol. 73:379-387. DOI: http://dx.doi.org/10.1007/s10327-0070045-5.

Wyczling D, Lenc L, Sadowski C. 2010. Comparison of disease occurrence and green leaf area (GLA) of winter wheat depending on the forecrop and differentiated fungicidal protection used. J Plant Protect Res. 50(4):489-495. DOI: http://dx.doi.org/10.2478/v10045-0100081-6. 